\title{
Ethnobotany of banana plants (Musa $x$ paradisiaca) of Palintang Hamlet, Cipanjalu Village, Bandung, West Java, Indonesia
}

\author{
JOHAN ISKANDAR, JOKO KUSMORO, MIRA MUBAROKAH, RUHYAT PARTASASMITA, \\ Department of Biology, Faculty of Mathematics and Natural Sciences, Universitas Padjadjaran. Jl. Raya Bandung-Sumedang Km. 21, Jatinangor, \\ Sumedang 45363, West Java, Indonesia. Tel./fax.: +62-284-288828. `email: ruhyat.partasasmita@unpad.ac.id; rp2010rikkyo@gmail.com
}

Manuscript received: 10 September 2018. Revision accepted: 21 October 2018.

\begin{abstract}
Iskandar J, Mubarokah M, Kusmoro J, Partasasmita R. 2018. Ethnobotany of banana plants (Musa x paradisiaca) of Palintang Hamlet, Cipanjalu Village, Bandung, West Java, Indonesia. Biodiversitas 19: 2059-2072. Rural people of West Java have traditionally farmed many varieties (landraces) of bananas (Musa x paradisca L) in the agroecosystem of homegardens and gardens. Because of the increasing human population, rapid rate of agricultural land conversion to other land uses, intensive penetration of market economy to rural areas, and introduction and selection in favor of banana landraces having good taste for culinary and high market price, some landraces of bananas have become rare, even locally extinct in rural areas. The main purpose of this study was to elucidate local knowledge of Palintang people on landraces, population, local farming management, and utilization of bananas. The mixed methods, qualitative and quantitative were applied in this study, while some techniques of collecting primary data, mainly observation, participant observation, semi-structured interview, structured interview, semi-quantitative population of banana plant were carried out. The results of study showed that 18 landraces of bananas have been recorded in Palintang hamlet. Local knowledge or traditional ecological knowledge of Palintang people on bananas have been predominantly obtained from individual personal experiences and from the parents and ancestors, inherited from generation to generation via oral communication. Most banana landraces cultivated by Palintang farmers have superior culinary aspect, particularly good taste, and high price. As a result, some landraces of bananas considered not having good taste and having low price have rarely been planted in the gardens. Banana trees have traditionally been cultivated by farmers of Palintang based on traditional ecological knowledge and which has been culturally embedded. There are 7 main stages of banana cultivation, namely preparation of banana suckers, land preparation, planting, caring, harvesting, post-harvesting management, and utilization of bananas for home consumption and sale through village middlemen and market. The banana cultivation has dramatically changed due to both ecosystem and rural community's socio-cultural changes.
\end{abstract}

Keywords: Banana, cultivation, landraces, local knowledge, Palintang, utilization

\section{INTRODUCTION}

Bananas are one of the most important fruits of rural areas in Indonesia, including West Java. Based on literature the cultivated bananas are usually identified as Musa paradisiaca, Family of Musaceae, and Order of Zingiberales. Of the 66 banana species in the world, 12 species have been recorded in Indonesia (Widjaja et al. 2014). Bananas, besides having a number of species, also have many varieties (landraces) in Indonesia. 'Landrace' in this paper is defined as a local category for grouping cultivated banana plants according to common characteristics reflected in specific vernacular names based on local people instead of grouping based on genetic composition according to Western knowledge or literature (Iskandar and Ellen 1999). Based on ethnobotanical study on bananas, at least 30 landraces have been recorded in Sukajaya Village, South Sumedang, West Java (Hehakaya 2010). Bananas have high diversity of both species and landraces in different areas of Indonesia, and Indonesia has been recognized as one of central areas of banana distribution in the world (Purseglove 1985). In addition, Indonesia has rich cultural diversity and bananas have been culturally cultivated in different agroecosystem types, including swidden (ladang or huma), homegarden (pekarangan), garden (kebun) and mixed-garden (kebun campuran) (Iskandar 1998; Iskandar 2016; Iskandar and Iskandar 2018; Iskandar et al. 2018; 2018c).

Bananas have made the biggest contribution to fruit productions in Indonesia. Approximately $30 \%$ of total fruit productions in Indonesia is contributed by bananas (Widjaja et al. 2014). Bananas have been traditionally utilized for various food uses, including dessert of ripe fresh banana fruit, boiled ripe banana fruit (pisang rebus), fried ripe banana fruit (pisang goreng), unripe banana fruit made into rujak bebek which is mixed with cassava or sweet potato and sauces, kolek pisang (banana mixes with sugar and coconut starch), banana crackers (kripik pisang) and traditional ritual offerings (Burkill 1935; Igarashi 1985; Iskandar 1998). In addition, leaves of banana have traditionally been used for wrapping cooked rice (bungkus nasi timbel). Since bananas have important various traditional purposes, the diversity of bananas must be conserved to fulfill the daily needs of rural people (Kusumaatmaja 2001; Iskandar and Iskandar 2011; Iskandar and Iskandar 2016b; Haspari et al. 2017).

Generally, nowadays the cultivation of bananas has been traditionally done by rural people across culture in Indonesia. For example, bananas have traditionally been farmed in various agroecosystems of West Java, including 
in homegardens, swidden (huma), gardens and mixedgardens instead of commercially farmed in the banana plantation (Karyono 1981; Iskandar and Iskandar 2011; Iskandar and Iskandar 2015). Today since the population of rural people have rapidly increased, agricultural lands have been continuously converted to non-agricultural purposes, and market economic system has intensively penetrated rural areas, the ecological and socio-economic and cultural aspects of rural people have dramatically changed. For example, banana production has decreased due to the decreasing agricultural lands that have been used for planting bananas. In addition, some local varieties (landraces) of bananas have been favorably selected by rural people because of their good taste and high market price. Conversely, some landraces of bananas considered not tasty and having low market price have been rarely farmed by rural people. Consequently, some local landraces of bananas have been extinct due to rapid changes of ecosystems and socio-economic and cultural aspects of people (Iskandar and Iskandar 2016a; Iskandar et al. 2018).

Some studies on bananas have been carried out by scholars in Indonesia. For example, study on varieties, uses, and traditional cultivation was undertaken in Sukajaya village, South sub-district, West Java. This research revealed that Sundanese people have rich traditional ecological knowledge (hereafter referred to as TEK) on bananas (Hehakaya 2010). Another study has been done on the grouping of species of bananas based on genome and kinship relationship on banana genome (Hapsari et al. 2017; Fitriyah et al. 2017).

This study was focused on TEK on bananas, namely on banana varieties (landraces), local knowledge sources of rural people on bananas, bananas farmed in the garden, and banana utilizations based on a case study in Palintang people of Bandung, West Java. The Palintang hamlet was chosen for the study due to some reasons, including the fact that this hamlet is located in the upland area of Bandung where most people work as vegetable farmers in the pine forest of Perhutani, and they have not been involved in wet-rice farming because there is no wet-rice field in the area (Iskandar et al. 2017).

\section{MATERIALS AND METHODS}

\section{Study site}

This research was carried out in Palintang Hamlet, Cipanjalu Village, Cilengkrang Sub-district, Bandung District, West Java, Indonesia (Figure 1).

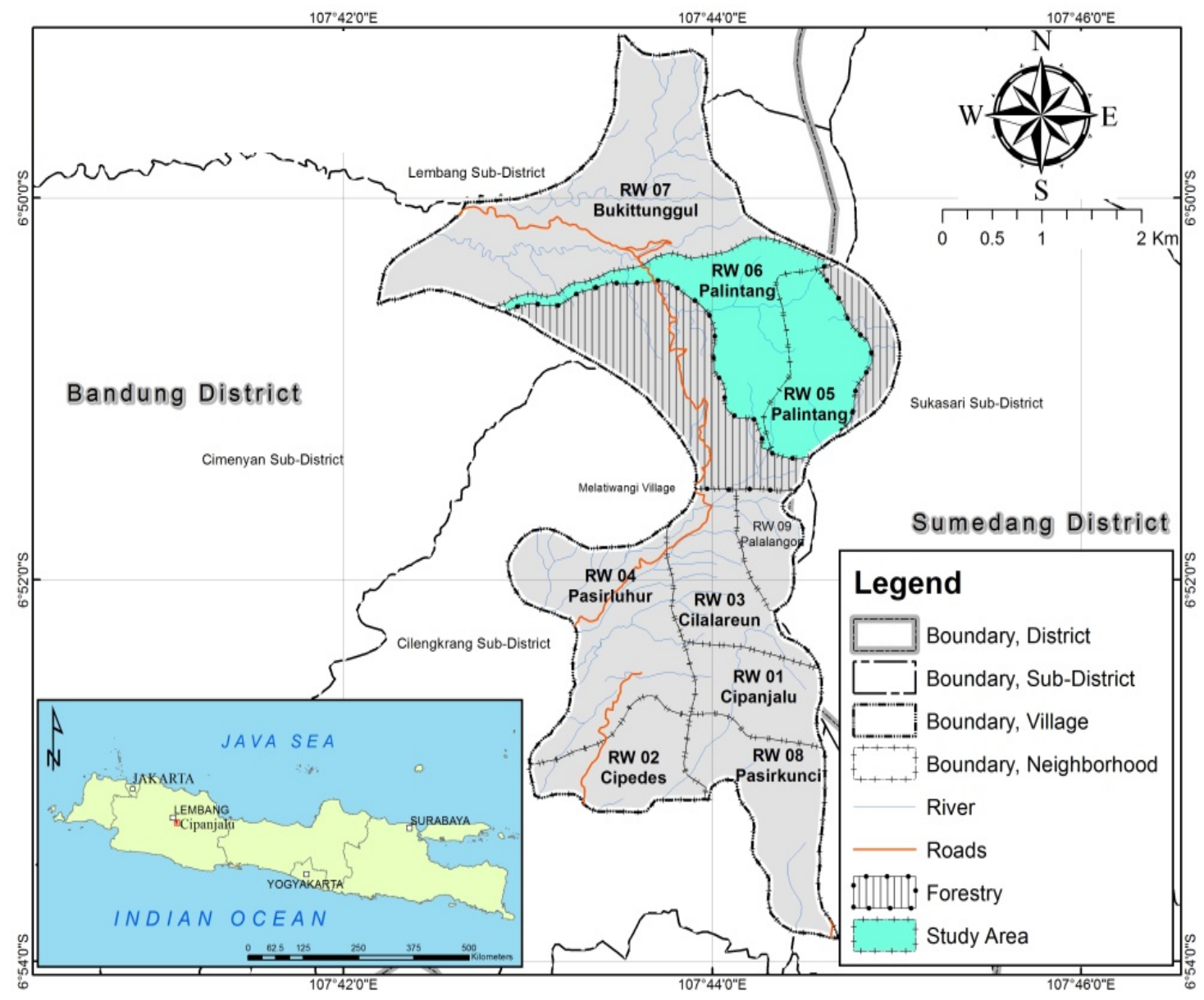

Figure 1. Study site Palintang Hamlet, Cipanjalu Village, Cilengkrang Sub-district, Bandung District, West Java, Indonesia (Iskandar et al. 2017) 
Geographically, Palintang is located approximately at $107^{0} 43$ '30"- $107^{0} 44^{\prime} 00^{\prime}$ N , 6045'15"-6051'30" E. Palintang Hamlet is situated about $8 \mathrm{~km}$ to the north of Ujung Berung, and is positioned approximately between 800 and 1,400 $\mathrm{m}$ above sea level. This hamlet is surrounded by pine forest (Pinus merkusii) and quinine (Cinchona calisaya) plantation. Administratively, to the north and east Palintang hamlet is bordered by the forest of Perhutani, to the south by Ciporeat village, and to the west by Bukit Unggul hamlet (Gunung Kasur).

The total population of Palintang in 2018 was 632 households. Most people of Palintang hamlet have main livelihood as farmers and farm laborers. The main agroecosystems of Palintang are the homegardens, gardens, vegetable gardens and coffee (Coffea arabica) plantations within the pine forest of the Perhutani by applying tumpang sari system, or mixed planting of coffee and pine (Iskandar et al. 2017). Banana trees have been commonly planted in the homegardens, gardens, and more recently both banana and coffee trees have been introduced in the Perhutani forest to minimize the vegetable gardens in the forest, to avoid soil erosion, to improve soil fertility, and to provide good income for the local people of Palintang Hamlet (Figure 2 and 3). Banana trees have been predominantly interplanted with other annual plants as well as perennial trees, including coffee, avocado (Persea americana), mango (Mangifera indica), pine, and suren (Toona sureni).

\section{Method}

This study used a mixture of qualitative and quantitative methods (Cresswell 2009; Iskandar 2018). Some techniques namely observation, participant observation, semi-structured interview, and survey of population and distribution of banana were applied to collect primary data in the field. Observation was aimed to observe the local environmental conditions, including the settlement and homegardens, gardens, and forest of
Perhutani. The participant observation was done by interviewing and participating in some informant activities of cultivation of bananas, including preparing land, planting, providing fertilizers, and harvesting the fruit. The competent informants, namely formal hamlet, and village leaders, male and female farmers, Perhutani staff, and middlemen were purposively selected to get some information of banana varieties, cultivation process, and utilization. The structured interview was undertaken using questioner with respondents who were randomly selected. The total number of respondents was determined using a statistical formula based on Lynch et al. (1974) and Iskandar (2018), as follows:

$\mathrm{n}=\frac{N \times Z^{2} \times P(1-P)}{N \times d^{2}+Z^{2} \times P(1-P)}$

Where:

$\mathrm{n}$ : Sample number (respondents)

$\mathrm{N}$ : Total population of households: 632 households $\square$

$\mathrm{Z}$ : Normal variable value (1.96)

$\mathrm{P}$ : Possible maximum proportion $(0.50)$

d : Error (0.10)

$\mathrm{n}=83$ households

To analyze the distribution and population of varieties (landraces) of bananas in gardens of Palintang hamlet, 30 samples of gardens of total 83 respondents were selected. In each garden sample, the numbers of varieties and individuals of banana were recorded to determine the SDR (Summed Dominant Ratio) of each variety (Iskandar and Iskandar 2016b).

\section{Data analyses}

Qualitative data collected by observation, participant observation, and semi-structured interview were analyzed by crosschecking to get valid data, summarizing, synthesizing, and making narration with descriptive and evaluative analysis (cf, Newing et al. 2011; Iskandar 2018).

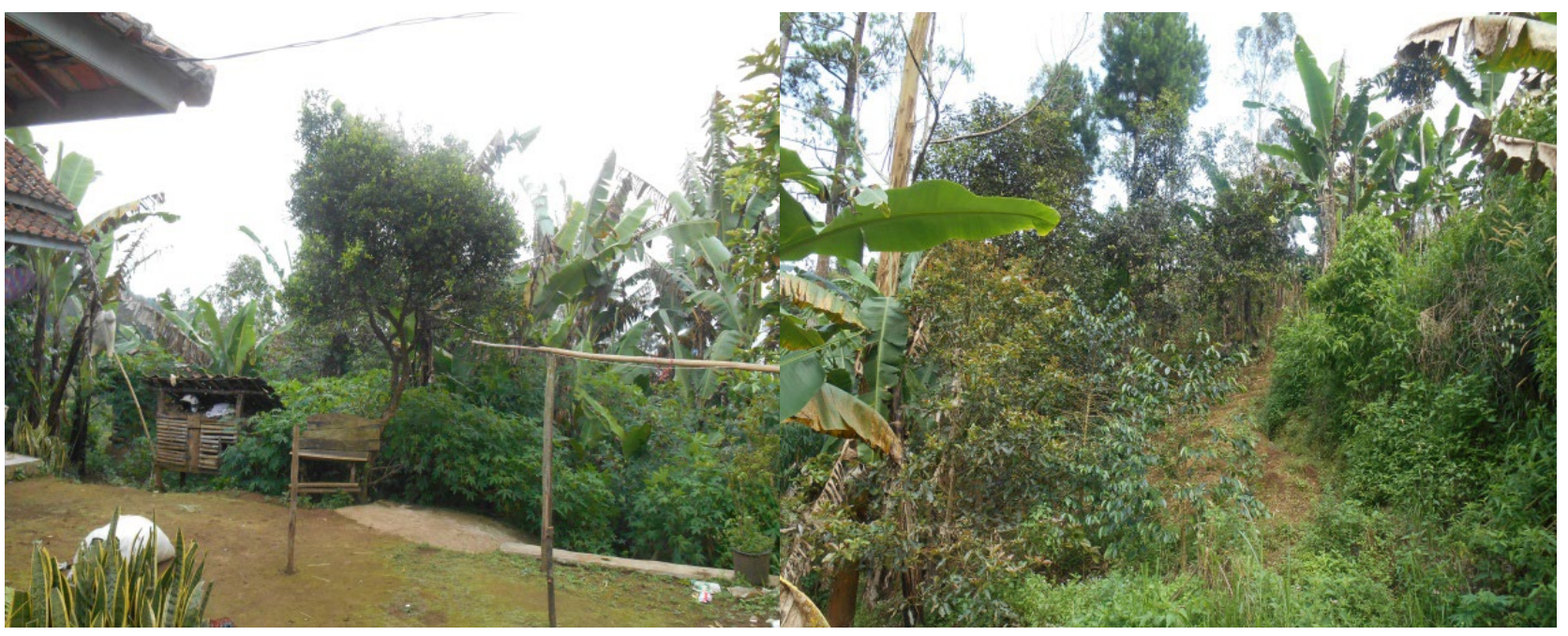

Figure 2. Banana trees have been predominantly planted in homegardens of Palintang hamlet, West Java, Indonesia
Figure 3. Banana and coffee trees have been introduced planted in the forest of Perhutani of Palintang hamlet, West Java, Indonesia 
The quantitative data collected by structured interview were analyzed by simple statistical calculations as follows (Warsito 1992):

$$
P=\frac{f}{N} \times 100 \%
$$

Where:

$\mathrm{P}$ : Percentage of the total answer of respondents

$\mathrm{f}$ : Number of respondent answers

$\mathrm{N}$ : Total respondents

The results of statistical analyses were narrated with descriptive and evaluative analyses, while the population and distribution of each banana landrace were analyzed using the formula of SDR (Summed Dominant Ratio) (Iskandar and Iskandar 2016b). SDR was calculated using the following formula:

$$
\begin{aligned}
& S D R=\frac{F r+D r}{2} \\
& \text { Fr }=\frac{\text { Frequency of a certain banana landrace } \times 100 \%}{\text { Total frequency of total banana landraces }} \\
& \text { Dr }=\frac{\text { Individual of a certain banana landrace }}{\text { Total individuals of all banana landraces }} 100 \%
\end{aligned}
$$

Where:

$\mathrm{F}$ : Absolute frequency of certain banana landrace found in all plots

$\mathrm{Fr}$ : Relative frequency

Dr : Relative dominance

\section{RESULTS AND DISCUSSION}

\section{Local knowledge of banana variations}

Banana is locally named by Palintang people as cau or pisang in Indonesian. Based on interview with informants 18 landraces of banana were recorded in Palintang hamlet (Table 1).

The number of banana landraces recorded in Palintang was lower than that recorded in Sukajaja Village of Sumedang documented by Hehakaya (2010) which was 30 . The low number of banana varieties in Palintang may be caused by many factors, including the high altitude of Palintang. The hamlet is located in an enclave area of the Perhutani forest area. Indeed, people have limited land size of homegardens as well as gardens for planting the banana trees. As a result, most people of Palintang have predominantly farmed the vegetable crops and banana trees in gardens of forest area. Based on the homegarden ecology in villages of Citarum watershed, it was revealed that there is a positive correlation between size of the homegardens and plant species diversity (Karyono 1981; Iskandar and Iskandar 2016b). In other words, the larger the size of a homegarden the more species of plants are found and vice versa.
According to the TEK of Palintang people (emic view), the landraces of bananas can be classified based on morphology of fruit, morphology of pseudostem, skin color of mature fruit, color of fruit flesh, the presence of seeds in flesh of fruit, culinary aspect, and their utilization (Table 1). On the other hand, based on Western knowledge the cultivated bananas are usually referred to as Musa $x$ paradisiaca $\mathrm{L}$ or synonym Musa sapientum $\mathrm{L}$ in Linnean binomial nomenclature, Family of Musaceace (Purseglove 1985). Variations or cultivars of banana can be identified and grouped based on 15 characters of determining genome by using score card of Simmond and Shepherd method (1982) (Fitriyah et al. 2017). Based on Western classification, banana cultivars are mainly genome groups. Variously cultivated bananas were originally from wild banana species, namely Musa acuminata Colla (with genetic composition of AA) and Musa balbisiana Colla (with genetic composition of $\mathrm{BB}$ ). On the basis of composition of genes of $\mathrm{AA}$ and $\mathrm{BB}$, some varieties (landraces) of bananas are found in Palintang, namely muli (AA), ambon Jepang, ambon lumut, and ambon bodas (AAA); raja cere, raja bulu, susu, and astrali (AAB); ampeyang, bogo and sewu (ABB); and manggala (BBB) (Purseglove 1985; Sudarnadi 1996). The genus of Musa has 66 species in the world, and originally comes from South East Asia, which is considered as the center of primary diversity of bananas, and bananas were initially domesticated in this region. Of the 66 species of bananas in the world, 12 species with various cultivars are recorded in Indonesia. However, nowadays, only 20 varieties (landraces) of bananas are registered in Indonesia, as presented in Table 2 (Widjaja et al. 2014).

\section{Sources of knowledge}

Most of respondents know about banana plant based on classification and nomenclature of local knowledge as level of folk species, and richer knowledge of varieties or folk varietal level according to Western botanical classification (cf. Berlin et al. 1973; Lizarralde 2004; Iskandar 2018). On folk varietal level, for example, banana (pisang) can be classified based on midrib base color, fruit shape, ripe fruit skin color, and the presence or absence of seeds in the fruit flesh (Table 1). Generally, based on the presence or absence of seeds, a total of 18 landraces of bananas in Palintang hamlet consisted of 16 varieties whose fruit does not contain seeds, and only two varieties, namely pisang manggala and pisang bogo which have seeds in the fruit. Based on the color of midrib, banana varieties can be classified into two groups. Most varieties have green and greenish midrib, and only two varieties have reddish midrib, namely pisang bawel and pisang bogo. In terms of utilization, most varieties of bananas are used as fresh fruit for human consumption. However, some landraces, including cau astroli, cau galek, cau sewu, and cau sewu have predominantly been consumed after having been cooked, including being fried, burned, and steamed instead of directly eaten as ripe fresh fruit. In addition, unlike other landraces, pisang manggala is not used for consumption because its fruit has seeds; instead, its leaves are used. 
Table 1. Various landraces of banana in Palintang Hamlet, Cipanjalu Village, Cilengkrang Sub-district, Bandung District, West Java, Indonesia

\begin{tabular}{|c|c|c|c|c|c|c|c|c|c|c|}
\hline \multirow{2}{*}{ Banana landraces } & \multirow{2}{*}{ Pseudostem } & \multirow{2}{*}{$\begin{array}{c}\text { Tree } \\
\text { tall }\end{array}$} & \multicolumn{2}{|c|}{ Leaves } & \multicolumn{6}{|c|}{ Fruits } \\
\hline & & & Texture & Midrib base & Ripe fruit skin color & Shape & Flavor & Texture & Seed & Flesh color \\
\hline Ambon Bodas & Green with brown spots & $2.5-3 \mathrm{~m}$ & Rather flexible & e Green & Yellow & Medium length & h Sweet & Soft & No seed & White \\
\hline Ambon Jepang & Green with brown spots & $1.5-2 \mathrm{~m}$ & Not flexible & Green & Yellow greenish & Medium length & h Sweet and fragrant & t Soft & No seed & White \\
\hline Ambon Lumut & Green with brown spots & $3-3.5 \mathrm{~m}$ & Not flexible & Green & Yellow-green with black spots & Medium length & h Sweet and fragrant & t Soft and fluffy & No seed & Yellowish \\
\hline Ampeang & Green red line & $2.5 \mathrm{~m}$ & Rather flexible & Redish & Yellow & Short fat & Sweet & Rather hard & No seed & Yellowish \\
\hline Astrali & Green yellowish & $3 \mathrm{~m}$ & Not flexible & Green & Green yellowish & Big length & Sweet & Rather hard & No seed & White \\
\hline Bawel & Green yellowish & $3.5 \mathrm{~m}$ & Rather flexible & Green rather whitish & Yellow greenish & Long little flat & Sweet & Rather hard & No seed & White \\
\hline Bogo & Green reddish & $2.5 \mathrm{~m}$ & Rather flexible & Reddish & Yellow & Short fat & Sweet and fragrant & t Soft & Little seeds & While \\
\hline Gembor & Green reddish slight blackish & $3 \mathrm{~m}$ & Not flexible & Reddish & Red & Short fat & Rather bland & Soft & No seed & White \\
\hline Golek & Green & $3 \mathrm{~m}$ & Not flexible & Green & Yellow with black spots & Big length & Sweet & Rather hard & No seed & White \\
\hline Manggala & Green yellowish & $2.5 \mathrm{~m}$ & Flexible & Green & Yellow & Angular shape & Not edible & Not edible & A lot of seeds & Yellow \\
\hline Muli & Green yellowish & $2 \mathrm{~m}$ & Flexible & Green & Yellow & Short round & Sweet & Soft & No seed & Yellow \\
\hline Nangka & Green yellowish & $3 \mathrm{~m}$ & Not flexible & Green whitish & Yellow greenish & Medium length & h Sweet & Rather hard & No seed & White \\
\hline Raja Bulu & Greenish & $3 m$ & Rather flexible & Green & Clean yellow & Medium length & h Sweet and fragrant & t Lembut & No seed & Yellowish \\
\hline Raja Cere & Dark green & $2.5 \mathrm{~m}$ & Not flexible & Greenish & Yellow green with black spots & Small short & Sweet & Soft & No seed & Yellow \\
\hline Ruhmid & Green with black spots & $1.5-2 \mathrm{~m}$ & Rather flexible & Green & Yellow-green with black spots $\square$ & Small short & Sweet & Soft & No seed & Yellow \\
\hline Sewu & Bright green & $4-5 \mathrm{~m}$ & Not flexible & Greenish & Yellow greenish & Short round & Sweet & Soft & No seed & Yellow \\
\hline Susu & Green & $2.5 \mathrm{~m}$ & Flexible & Greenish & Yellow & Short & Sweet & Soft & No seed & Yellowish \\
\hline Tanduk & Bright green & $3.5 \mathrm{~m}$ & Rather flexible & Green & Yellow greenish & Angular length & Sweet & Soft and fluffy & No seed & Yellowish \\
\hline
\end{tabular}


Table 2. Local varieties of bananas registered in Indonesia

\begin{tabular}{ll}
\hline $\begin{array}{l}\text { Name of local banana } \\
\text { varieties }\end{array}$ & Origin/proposer \\
\hline Pisang agung semeru & District Lumajang, East Java \\
Pisang mas kirana & District of Lumajang, East Java \\
Pisang kapok manurun & Banjar, South Kalimantan \\
Pisang talas & District of Balangan, South Kalimantan \\
Pisang telur & Kerinci, Jambi, Sumatra \\
Pisang sari & Jimbaran, Bali \\
Pisang raja nangka & District of Meringin, Jambi \\
Pisang raja bulu kuning & District of Bogor, West Java \\
Pisang ketip gunung sari & West Lombok, West Nusatenggara \\
Pisang unti saying & Selayar, South Sulawesi \\
Pisang gebyar & District of Batang, Central Java \\
Pisang jantan piaman & Pariaman \\
Pisang mulu bebe & North Maluku \\
Pisang kapok pontia & District of Kubu Raya \\
Pisang raja lawe & District of Banjarnegara \\
Pisang mas bernas & Jambi \\
Pisang limba & North Sulawesi \\
Pisang ratahan & North Sulawesi \\
Pisang barangan merahi & District of Serdang \\
Pisang kapok bangun sari & District of Serdang \\
\hline Source: Widjaja et al. (2014)
\end{tabular}

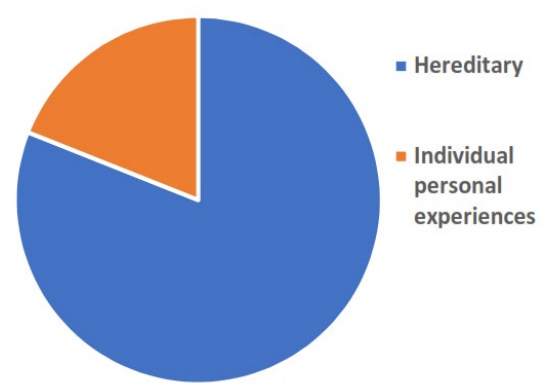

Figure 4. The way of obtaining local knowledge on banana of Palintang people, West Java, Indonesia

Most of respondents obtained TEK on banana, including its varieties, cultivation, and utilization from individual personal experiences $(81 \%)$, and the rest $(19 \%)$ obtained from the parents and ancestors, inherited from generation to generation via oral communications using mother tongue, namely Sundanese language (bahasa Sunda) (Figure 4).

This result is in line with those of studies undertaken by some scholars, which mentioned that because rural people traditionally have intensive interaction with their environment, over time, they obtain various local knowledge or TEK, including knowledge on bananas and this knowledge is transmitted among community members (cf. Boyd and Richerson 1985; Hewlett and Cavalli-Sforza 1986; Puri 1997; Lizarralde 2004; Iskandar and Iskandar 2005; Iskandar 2018; Yenrizal 2015). TEK may be defined as 'a cumulative body of knowledge, practice, and beliefs, evolving adaptive processes and handed down through generations by cultural transmission, about the relationship of living beings (including humans) with one another and with their environment (Berkes 2008). TEK is different from the scientific Western knowledge in that it is predominantly qualitative instead of quantitative, mostly intuitive instead of pure rational, holistic instead of reductionistic, emphasizing on empirical aspects instead of theoretical analysis, and based on diachronic data (long run experiences) instead of synchronic data (short run basis) (Ellen et al. 1993; Iskandar 2018).

Palintang people are a local community living in the enclave area of the Perhutani forest. Traditionally they have been agriculturalist, growing vegetables and other crops in their lands and in the Perhutani forest. One of the most impressive features of Palintang TEK is that the majority of people can identify various bananas. Based on interview, it has been revealed that the distribution of knowledge with Palintang communities is not homogenous. Generally, old people and people who are intensively involved in planting various crops in their garden have greater banana knowledge than the young people and nonfarmers. According to environmental history, most farmers of Palintang pass through three general stages in learning bananas which can be labeled 'parental', 'peer', and 'individual' learning. These categories are based on the dominant source of knowledge of bananas during each stage. Parental learning involves fathers and other elders informally teaching children. Learning at this stage is equivalent to 'vertical cultural transmission' (cf. Puri 1997), because socially transmitted banana knowledge is passed from generation to generation. Peer learning occurs in groups of young generation, who have started practicing planting crops, including banana. Learning in the stage of peer learning is equivalent to horizontal cultural transmission, because it occurs between members of same generation of Palintang community. Individual learning happens during adult period, when they often prefer to cultivate banana crops by themselves, before they have children to teach and after their children start to cultivate with their peers. Thus, elders end up farming crops by themselves or with a single companion, rather than planting banana crops in a group of farmers, and knowledge learning in crops, including banana in both garden and forest of Perhutani is predominantly individualistic. Based on the transmission of local knowledge, it can be inferred that respondents of Palintang people have obtained knowledge of bananas mainly from personal experiences $(81 \%)$, after processing of parental and peer learning, during children and adolescent stage, and the rest (19\%) obtained knowledge from the parents as mentioned earlier.

\section{Population of bananas in the garden}

Various banana landraces are predominantly found in several agroecosystem types, including homegarden, garden and forest garden of Perhutani forest. Traditionally, banana trees in both gardens and forests have been predominantly planted by interplanting with other annual and perennial plants, including beans, cassava (Manihot eculenta Crantz), avocado (Persea americana Mill), coffee (Coffea arabica L), suren (Toona sureni), and bamboo (Gigantochloa apus (Schult. F.) Kurz) (Figure 5). 


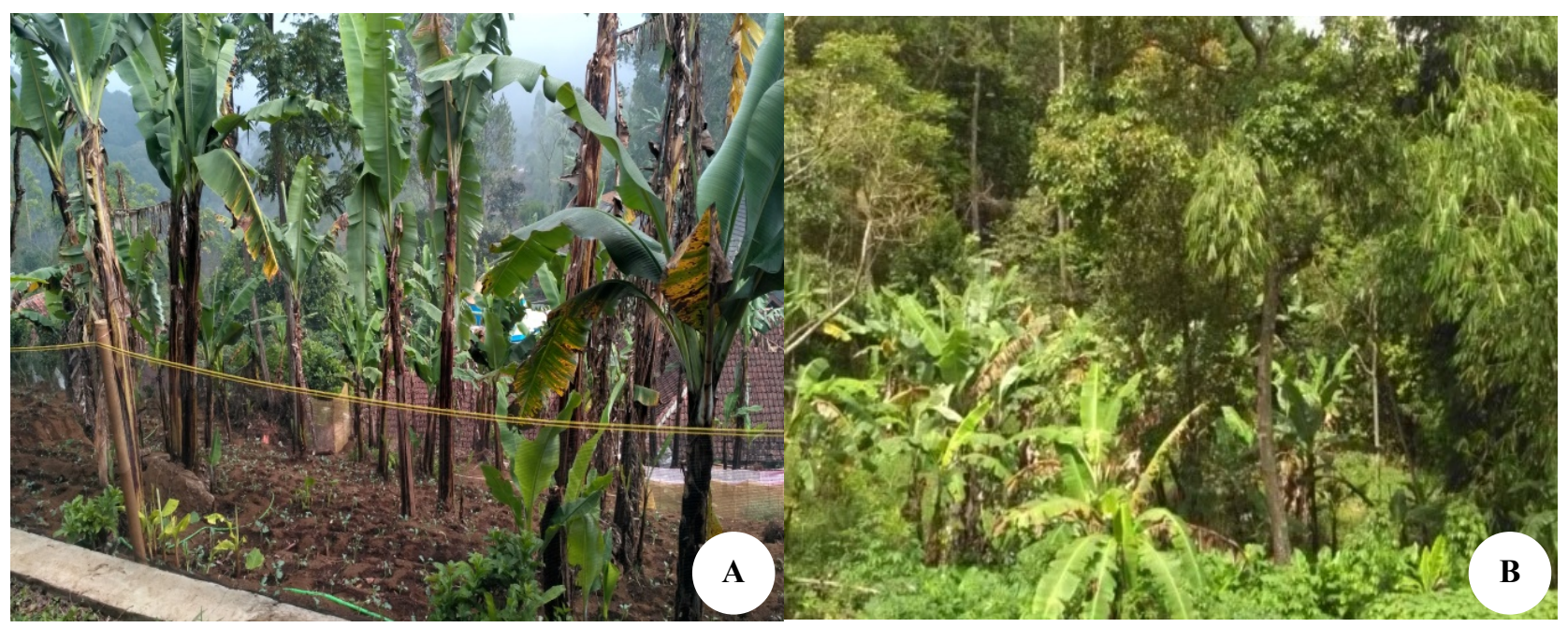

Figure 5. A. Banana trees are interplanted with annual crops, including beans, and other perennial trees, such as suren (Toona sureni). B. Bananas are interplanted with other perennial crops, including avocado (Persea americana) in garden of Palintang hamlet

Table 3. SDR (Summed Dominant Ratio) value of banana landraces recorded in the garden agroecosystem of Palintang, West Java, Indonesia

\begin{tabular}{lrrr}
\hline $\begin{array}{c}\text { Banana } \\
\text { variations }\end{array}$ & $\begin{array}{c}\text { Relative } \\
\text { frequency } \\
\text { (FR) }\end{array}$ & $\begin{array}{c}\text { Relative } \\
\text { dominance } \\
\text { (DR) }\end{array}$ & $\begin{array}{c}\text { Summed } \\
\text { dominant } \\
\text { ratio (SDR) }\end{array}$ \\
\hline Ambon bodas & $5.64 \%$ & $4.59 \%$ & $5.11 \%$ \\
Ambon Jepang & $6.45 \%$ & $8.17 \%$ & $7.31 \%$ \\
Ambon Lumut & $24.19 \%$ & $22.61 \%$ & $23.40 \%$ \\
Ampeang & $1.61 \%$ & $1.63 \%$ & $1.62 \%$ \\
Astrali & $2.41 \%$ & $2.72 \%$ & $2.56 \%$ \\
Bawel & $4.03 \%$ & $3.26 \%$ & $3.64 \%$ \\
Bogo & $1.61 \%$ & $1.63 \%$ & $1.39 \%$ \\
Gembor & $0.80 \%$ & $0.81 \%$ & $0.80 \%$ \\
Golek & $1.61 \%$ & $1.08 \%$ & $1.34 \%$ \\
Manggala & $1.61 \%$ & $1.63 \%$ & $1.62 \%$ \\
Muli & $16.93 \%$ & $23.70 \%$ & $20.31 \%$ \\
Nangka & $5.64 \%$ & $4.35 \%$ & $4.99 \%$ \\
Raja Bulu & $6.45 \%$ & $6.53 \%$ & $6.49 \%$ \\
Raja Cere & $14.51 \%$ & $13.07 \%$ & $13.79 \%$ \\
Ruhmid & $1.61 \%$ & $1.08 \%$ & $1.34 \%$ \\
Sewu & $0.80 \%$ & $0.54 \%$ & $0.67 \%$ \\
Susu & $1.61 \%$ & $1.08 \%$ & $1.34 \%$ \\
Tanduk & $2.41 \%$ & $1.63 \%$ & $2.02 \%$ \\
\hline
\end{tabular}

Among 18 varieties of bananas in 30 gardens or plots in hamlet Palintang, 7 landraces have been predominately recorded, namely Ambon lumut (23.40\%), Muli (20.31\%), Raja Cere (13.79\%), Ambon Jepang (7.31\%), Raja Bulu (6.49\%), Ambon bodas (5.11\%), and Cau nangka (4.99\%) (Table 3).

The value of SDR (Table 3) in Palintang gardens is presumably related to the quality of banana landrace, including fruit texture, and flavor. For example, pisang/cau ambon lumut, ambon Jepang, muli, and raja cere have high SDR value than other varieties because the ripe fruit of these varieties has smooth texture and good taste (sweet and tasty) as dessert. Because of the good quality of these landraces, they are preferred for household consumption, and the demand of these landraces has increased. As a result, these landraces are predominantly sold in markets and small shops (warung). For example, based on ethnobotanical study on edible plants traded in the traditional market, banana landraces of ambon lumut and muli have been predominantly recorded in the traditional market of Ujungberung, Bandung, located close to Palintang hamlet (Iskandar et al. 2018a). Conversely, banana variety of manggala, that has seeds in the flesh and does not taste good, is rarely consumed as fruit, less demanded by people and its price is low. Consequently, this variety has rarely been planted in the gardens, as indicated by low value of SDR (Table 3 ). Instead of its fruit, it is its leaves that are used by the people. Since the intensive selection of the Palintang, some landraces of banana have not been in demand by rural people, and these landraces have rarely been planted by rural people and this trend may cause local extinction (cf. Iskandar et al. 2018b). This is very detrimental to biodiversity conservation for the long term, because the extinction of local varieties of bananas also causes the loss of various biological resources used for plant breeding program to produce new varieties, such as those with high production and resistance to various environmental disturbances.

\section{Cultivation of banana}

Cultivation of banana has been undertaken by Palintang people based on their TEK embedded in their culture. There are 7 stages of the cultivation of banana, namely preparation of an underground stem with sucker (nyiapkeun bibit), preparation of land (nyiapkan lahan), planting (melak), caring (ngarawat), harvesting (manen cau), and utilization.

\section{Preparation of banana sapling (nyiapkeun bibit)}

Before land preparation and planting of banana trees in a garden, first of all, an underground stem with sucker (bibit tangkal cau) is prepared. The underground stem with sucker is obtained by separating the new shoot, in the form of individual young banana or an underground stem with 
suckers, from the parent banana plant. The individual banana suckers, particularly the healthy ones with good buds, are properly selected from mature parent trees. The banana suckers are taken not from mature parent trees that are being attacked by diseases. Therefore, if the banana suckers are vegetatively planted later on, they can grow properly and produce a lot of good fruit.

According to interview with informants, banana underground stem with suckers are obtained not only from the parent trees that have been available in the garden of each household but also from the barter with other farmers in the village. In addition, several introduced varieties of bananas, including cau sewu are obtained by buying from a seller who sells seedlings at a kiosk. A total of $77 \%$ of respondents have got banana seedlings from vegetative propagation of existing parent pseudostems, and $2 \%$ got from buying at agricultural kiosks (Figure 6).

The underground stem with suckers of banana landraces of cau sewu or pisang seribu that has specific characteristics, including length of bunches is approximately 2.5-3 meter, has been mainly obtained from buying. It has a lot of fruit, and as a result, it is popularly called cau sewu that means a thousand units of fruit. Another characteristic of cau sewu is its small fruit, and therefore this variety is predominantly used for esthetical function in homegarden instead of production purpose.

The banana suckers for planting are commonly taken from the mature parent's pseudostem. They are separated (ditugar) by cutting using hoes (pacul). According to informants, the suckers must be properly selected for good individuals, such as having been more than two years old. Since suckers are properly taken, the banana parents are not disturbed. As expressed in rural people term, the banana parent pseudostems are not 'angry' as their children (suckers) are taken.

The suckers of banana that have been separated from the parent trees may not be stored for more than 5 days, because the suckers will rot if stored too long without growth media. The good sucker for planting is a banana shoot with a height of 1-1.5 meters and has at least 2 leaves, particularly individuals of sucker with smaller leaf width are preferred. The banana sucker that has just been removed is cleansed from soil, and all roots are cut to stimulate new root growth after planting. Banana sucker is put in a shaded place for 1-2 days, and is ready to be planted in a garden (kebon).

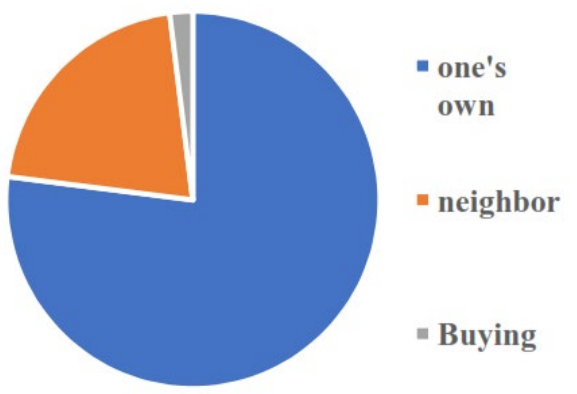

Figure 6. The way of obtaining young banana tree seedlings for replanting in gardens of Palintang people, West Java, Indonesia

\section{Land preparation}

The lands in the form of garden in Palintang used for planting banana are private land owned by each household and forest area of the Perhutani. Farmers may cultivate crops, including banana in forest of Perhutani in an intercropping (tumpang sari) program of Perhutani. Based on Perhutani regulation, rural people of Palintang are allowed to practice garden cultivation, but have duty to maintain forest plants. They plant coffee (Coffea arabica L) and banana (Musa x paradisiaca L) trees to provide income for local rural people and conservation of forest (Iskandar et al. 2017). Bananas are predominantly planted in combination with coffee trees and planted between vegetable crops (tumpang sela). Other land use types, homegarden and dry land at the edge of pond are also commonly planted with bananas.

Land preparation for planting banana in a garden has several stages. First, the grasses and shrubs are cut by chopping knives (parang), machetes (bedog or golok), and hoes (cangkul or pacul). Cutting of grasses and shrubs is named ngababad that is undertaken during the dry season. Vegetation biomass is collected, made into several piles (dionggokeun), and dried with direct sunlight. Second, the dry vegetation biomass is burned (ngahuru). The residual ash from burning (abu sisa ngahuru) is poured around the holes for planting banana sucker which is aimed to improve soil fertility. Because the residual ash from burning consists of rich nutrients, including potassium, calcium, and magnesium, it can be used as source of nutrient for banana trees (cf. Ekawati and Zasli 2012)

Third, the land is loosen using hoes and, in the same time, the rest of weeds, including alang-alang/eurih (Imperata cylindrica (L) Raeschel) are totally cut (ngalenangkeun). If the alang-alang has not been totally cut, this grass will disturb crops, including bananas. Imperata grass is an annual terrestrial weed that has the ability to develop rapidly, and can grow anywhere including infertile land, ex-forest area and abandoned land (Nasution 1986).

Forth, since bananas must be planted in holes, holes are made. The size of a hole is usually $0.5 \mathrm{~m}$ deep and $0.5 \mathrm{~m}$ in diameter. Each hole is added with chopped banana pseudostems and residual chopped saplings as organic fertilizers. In addition, inorganic fertilizer of Urea mixed with organic fertilizer namely the remaining ash from burning of grasses and shrubs, and ash of the kitchen stove is also added in holes, and the holes are covered with soil. Fifth, the chopped banana pseudostems and urea are buried in the holes for several days so that they decay in the hole. According to Sriharti and Salim (2008), banana wastes, including pseudostems are organic substances that can be used for making compost for agricultural crops. It has also been known that bananas respond well to added nitrogen and they have a high potassium requirement (Purseglove 1985). In other words, Palintang farmers have been able to combine knowledge by applying organic fertilizers as tradition in planting bananas with inorganic fertilizers, including Urea based on Western knowledge for planting bananas in this time (cf. Iskandar and Ellen 2007). 
The length of time for burying of chopped banana stems, ash, and Urea is about 2-3 weeks, then the planting hole is opened and ready to be planted with bananas. Preparation of this land is undertaken during the dry season between June and October, so when the rainy season arrives, the land is ready to be planted with bananas.

\section{Planting}

Planting of bananas is predominantly done at the beginning of the rainy season in November and December. Rural people of Palintang know traditional calculation of time (mangsa) is based on their TEK. As a result, like traditional swidden farmers in South Banten and South Cianjur, West Java, they can predict the appropriate time for planting bananas (Iskandar and Iskandar 2016c; Iskandar, Iskandar and Partasasmita 2016). In traditional Sundanese calendar, 12 times (mangsa) are recognized in one year, namely kasa (41 days), karo (23 days), katiga (24 days), sapar (25 days), kanem (43 days), kapitu (43 days), kadalapan (26/27 days), kasalapan (25 days), kasapuluh (24 days), hapit lemah (23 days), and hapit kayu (41 days). According to their tradition, the appropriate time to plant bananas is between the fourth month (mangsa sapar) and sixth month (mangsa kanem), which is usually at the end of dry season and at the beginning of rainy season, between November and December.

Planting of bananas in a garden has been undertaken in two main stages. Firstly, the land is prepared, particularly holes are dug for putting banana suckers. The planting distance is approximately $2.5 \mathrm{~m} \mathrm{x} 3 \mathrm{~m}$, if bananas are planted in the monoculture of garden system. However, if bananas are interplanted with of other crops such as coffee and avocado, the planting distance is approximately $5 \mathrm{~m} \mathrm{x}$ $10 \mathrm{~m}$ or they are planted on the edge of the cliff (pinggir tebing) of the garden. An underground stem with suckers (benih pisang) selected to be planted are the individuals which have small leaves or which have already had leaves, but all the leaves are cut, except for the young leaves that are still rolling (pucuk daun ngora). The cutting of leaves is undertaken to reduce evapotranspiration. Based on plant physiology, reducing the number of strands and cutting leaves will reduce the occurrence of water evapotranspiration, because when the area and number of leaves are reduced, the number of stomates, through which the plants loses water, will be reduced too. (Meltin 2009).

Secondly, planting banana, namely putting a sucker in a hole previously prepared, and the hole is covered with soil. As a result, the base of the underground stem with suckers is covered with soil, and the surface of the soil is covered with chopped banana pseudostems (bagedor) which functions as organic fertilizers (Figure 7). If the sucker (benih pisang) is too high, it must be supported by a bamboo stem (dipancuh) so that the banana stem does not fall if there is strong wind.

\section{Caring of banana trees}

The caring of banana is undertaken by farmers to ensure that the plants grow properly and produce good fruit. The first step is removing the grasses growing around the plants using a small hoe (kored). All weeds are buried around the plants as organic fertilizers. After weeding, 15 days and 20 days after planting, the plants are fertilized. Fertilizer is given by sprinkling fertilizer around the plants at a distance of about $30 \mathrm{~cm}$ from the base. Before sprinkling the fertilizer, a circular ditch of about $10 \mathrm{~cm}$ width is made first, and the fertilizer is sprinkled into the ditch and then it is covered with soil. Some fertilizers mostly used by farmers are organic fertilizers, such as sheep and chicken dung and inorganic fertilizers, such as urea and KCL with a proportion of $3: 2$. The dung of chicken is not directly given because it is still hot. So, the dung is left between 4 days and 7 days before it is used as fertilizer. In a certain case, the banana trees are not fertilized by farmers because the bananas are sometimes interplanted with other crops such as vegetables which are commonly fertilized intensively.

Seventy (70) percent of respondents used inorganic fertilizer of Urea and KCL, 17\% applied fertilizer of animal dung, and $13 \%$ did not apply fertilizer because the banana plants have indirectly obtained fertilizer from the fertilizer given to vegetables which are interplanted with banana trees (Figure 8).

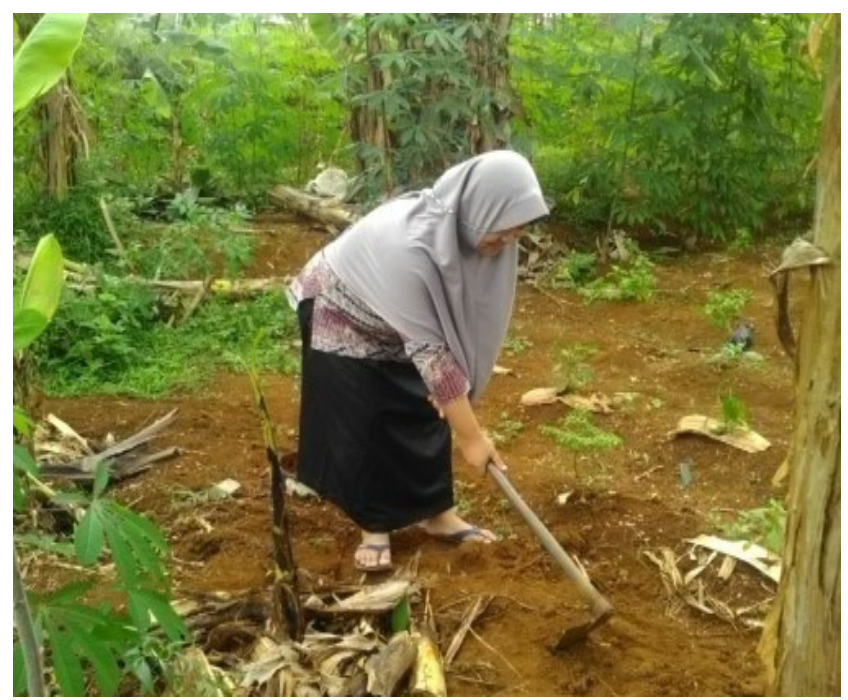

Figure 7. An underground stem with suckers is being covered with soil and its top is covered with chopped banana pseudostem as organic fertilizer $\square$

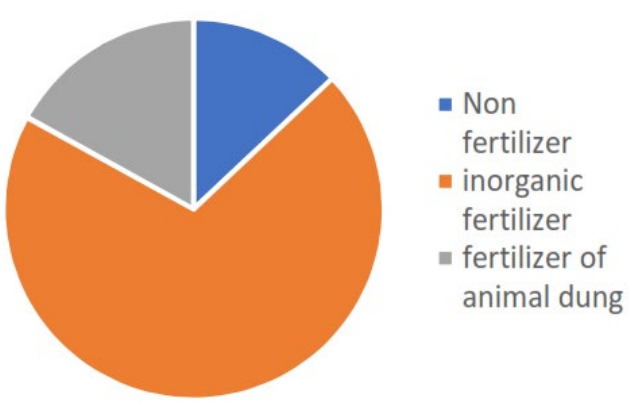

Figure 8. Cultivation of banana was undertaken by Palintang people, West Java, Indonesia with provision of fertilizers and without provision of fertilizers 
Ecologically, bananas require considerable amounts of mineral nutrient to maintain yields and these can be supplied by growing them on very fertile soils or applying fertilizer regularly. They have high demands for nitrogen and potassium (Purseglove 1985). In this case, Palintang farmers appropriately provide fertilizer urea and KCL containing nitrogen and potassium.

In addition to fertilization, another effort for caring banana trees is the cutting of dry dead leaves (karakas), undertaken any time, and the non-dry leaves, about 7 leaves per tree, are left on the tree to continue growing. The main purpose of cutting the dry dead leaves (perempalan) is to maintain environmental hygiene to prevent the attack of pests and diseases. The cutting of leaves is mainly done for bananas that have too many shoots.

Since the shoots of banana have grown from base of an underground pseudostem (bonggol) of parent, banana leaves produce a lot of banana clumps (dapuran cau). In one clump no more than four individual shoots are left to grow, because too many shoots will reduce the fruit production. As a result, several individual shoots are cut and chopped to be used as organic fertilizer for the clump of banana.

Some pests have attacked bananas. For example, a banana worm (cacing cau) has been popularly known by Palintang farmers as a pest attacking the pseudostem of bananas. Based on Western knowledge (literature), the banana worm that commonly attacks the pseudostem of banana is a nematode, namely Perionyx excavatus (Purnomo et al 2017). This nematode predominantly lives in between banana midribs, and if this nematode lives for a long time, it may cause the bananas to wither and finally die. If one midrib has been attacked by a banana worm, other bananas of the same clump may also be attacked and may die.

Another nematode has attacked mostly the underground pseudostems and roots, namely Rotulenchus similis or Radopholus similis (Rahmawati 2016). This kind of nematode is popularly named by Palintang farmers as janggel pest (hama janggel). Bananas may wither if they get janggel attack, causing cavities in base of pseudostems and swelling of roots. To prevent worm attacks of both underground and above ground pseudostem, some efforts are undertaken by farmers, including cutting all the pseudostem, without using pesticides, while the clumps attacked by the pests are left for a while or replaced with other bananas. This is undertaken to break the spread of the pests to other banana trees.

In addition, there is a pest which predominantly attacks leaves of bananas, called hama ulat daun (leaf caterpillar pest), namely Erienota thrax. The attacked leaves roll into a tube and are torn until all the leaves are gone. E. thrax is recognized as the larvae of Hesperiidae an insect that usually lives in bananas (Pratiwi et al. 2014).

Pest attacks on banana leaves usually occur at the beginning of the dry season. Banana leaf pests should not be disturbed or sprayed with insecticides because they will not interfere with the development and quality of banana plants. According to the Palintang farmers if the banana plant is affected by caterpillars, it means that the banana leaves are being used for a ceremony (hajatan) needed by their ancestors (leluhur), so if the leaves are sprayed with insecticides poisoning may occur, and the ancestors will be angry. As a result, the production of bananas will decrease. In terms of environmental conservation, belief systems serve as adaptive functions for human societies and their local environment (Lovelace 1984; Dove et al. 2005).

Meanwhile, based on Western knowledge (ethical view), according to Kalshoven (1981), E. thrax is an insect from the Order of Lepidoptera that lay eggs and the eggs hatch into white larvae. The larvae will cut and roll leaves on an oblique basis. The larval stage will take 28 days. At this larval stage, all the leaves on the banana plant will be exhausted except for the tops that have not been opened. The larvae will develop until they turn into imago in the form of brown butterflies that will suck nectar and help the pollination of banana flowers. So, when a caterpillar that damages the banana plant is sprayed with insecticides, the larvae will die and will not become an imago (butterfly), and there will be no E. thrax butterfly adult which fly in the evening and early morning and feed on nectar may help pollination on banana and the production of banana fruit will not be maximized (Kalshoven 1981).

The belief of the people of Palintang hamlet will indirectly help the efforts of conservation of an insect, $E$. thrax, and the balance of the ecosystem will be maintained because it provides the main food source for the ladybug killer Rhynocoris fuscipes so that the energy transfer path will not be disrupted (Bellows and Fisher 1999).

However, with the development of a commercial vegetable farming system in the Palintang hamlet, synthetic pesticides have been intensively used, also for bananas. Consequently, the intensive used of pesticides in bananas and vegetables has provided not only positive aspects, including killing the pests, but also negative aspects, including killing the predators of the pest and polluting the environment (Iskandar et al. 2017).

\section{Harvesting}

The banana pseudostem will start to produce a flower spike or inflorescence (mologong) some 8-10 months after planting. One bunch consists of 7 hands of banana fruit (uler). The number of hands of each bunch varies among landraces of bananas. The development stage into maturity, after last flowers on the bunch bloom, marked by the growth of would-be banana fruit (uler) proceeds very slowly, immediately after the remaining male flower (jantung pisang) is cut.

The cut tip of the low part of bunch, near the male flower (jantung pisang) is wrapped using a small plastic bag that has been filled with little urea fertilizer and the plastic is tied using a rubber band. It is aimed to get more production of fruit hands on a bunch. Moreover, if banana fruit on a bunch looks mature, the fruit is wrapped by a plastic bag (kantong plastic) or a gunny sack (karung goni) measuring $1 \mathrm{~m} \mathrm{x} 45 \mathrm{~cm}$. It has a special function to protect the fruit from damage by insects and disease and friction of banana leaves (Figure 9). Wrapping the fruit, particularly for ambon lumut landrace is done to get good fruit skin, 
without black spots. A high banana tree that has a lot of fruit is usually supported using a bamboo stalk, so as not to easily collapse when it is blown by strong winds.

Harvesting of banana fruit is usually undertaken approximately 3-4 months after the appearing of flowers or about 1 year after planting of sucker. The way people know that bananas are ready to be harvested, among others, is by looking at the condition of the flag leaves that have dried up: not much of the leaf midrib is collapsed, the pistil is easily broken, the fruit is fully developed and the fruit skin is bright.

Harvesting of banana is done by cutting the pseudostem using a machete (golok or bedog), and a banana bunch is kept from falling to the ground to prevent damage of the fruit. The bunch of banana is cut about $30 \mathrm{~cm}$ from base of the top of the pseudostem, as high as $0.7 \mathrm{~m}$ to $1 \mathrm{~m}$ from the base of the pseudostem on top of soil. This method is intended to trigger the growth of suckers or young shoots.

According to the perception of Palintang people (emic analysis), if harvesting banana fruit is done only by cutting off the part of the bunch without cutting down the pseudostem, the plant will get unhealthy (gering nangtung) or 'like a healthy person but actually unhealthy'. Based on Western scientific knowledge (etic analysis), unhealthy banana that is called by local people is that the banana plant remains standing but will eventually rot and will become a source of disease for the clump of plants.

Harvesting bananas are done once a week, because when one banana tree is old and ready to be harvested, next week there will be another tree that is ready to be harvested. In other words, harvesting bananas can occur continuously over time. One spike (saturuy) on a bunch of landrace of ambon lumut that has been harvested will produce approximately between 12 kilograms and 15 kilograms of banana fruit.

\section{Post harvesting management}

After the banana fruit has been harvested, the hands of banana fruit on a bunch are separated from each other by carefully cutting them using a sharp knife (Figure 8). Then, the fruit is incubated (dipeuyeum) for a couple of weeks. The process of ripening banana fruit is done to get banana fruit hands for sale ripen evenly.

In the past, the process of ripening banana fruit was undertaken by putting banana fruit in a large hole in the ground filled with various leaves of plants, including suren (Toona sureni (Blume) Merr) and smoked via a bamboo stem with blowing of traditional fan of bamboo. Another method of ripening banana fruit was by putting the fruit in a bamboo basket and wrapped the basket with various plants leaves, including dry banana leaves. Still, another method was wrapping carbide in cloth and storing it in a pile of bananas. This was undertaken inside the house. However, the ripe banana fruit will be hard for selling due to the odor remaining in the fruit and black color of banana skin.

Today, the process of ripening of banana fruit is done mostly using substances for fruit ripening that are widely sold in stalls or agricultural shops. The stimulating agent used is a form of powder-stimulating substance with the trademark known by farmers as 'cepa'. Traditionally, this stimulant substance is known by Palintang community as a drug. The dose of this stimulant is approximately a table spoonful of cepa mixed with about 5 liters of clean water, and the banana fruit is washed (dimandikan) in the cepa solution.

The fruit that has been washed is then dried for about 30 minutes or until its surface is no longer, and then it is stored in the house by stacking it in the corners of the room and wrapped it using plastic (Figure 10). Banana fruit will ripen perfectly after having been ripened for 3 days. In Western knowledge, the ripening using stimulants can trigger the work of ethylene in fruit so that the ripening process of the fruit can take place more quickly (Ridyanty et al. 2015). Ripening using stimulant substances will not cause odor, and the banana skin still looks smooth, and the level of toxicity becomes less and will not damage the environment with the residues produced

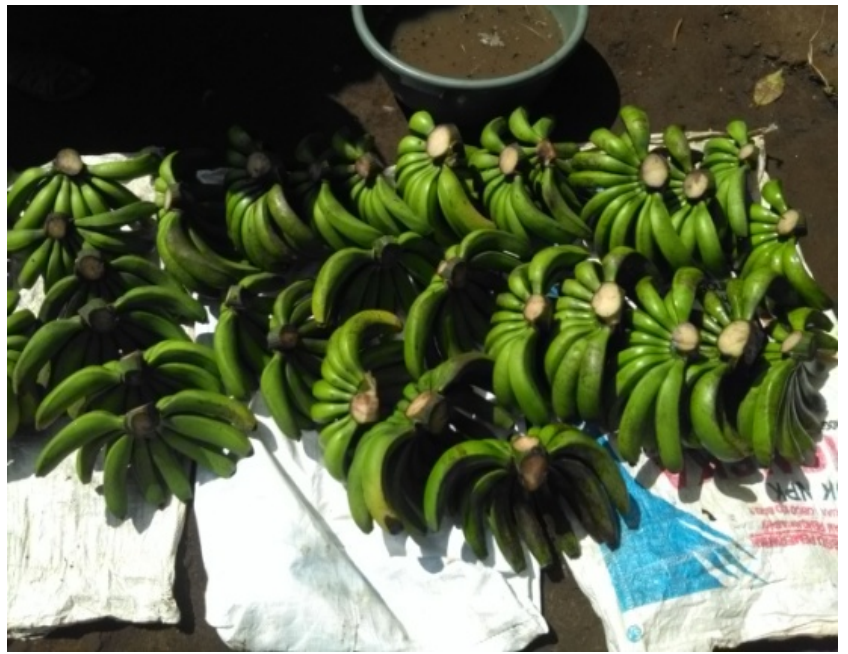

Figure 10. Harvested ripe banana fruit
Figure 9. Banana fruit is wrapped with a plastic bag and a gunny sack to protect it against pests and diseases. 
Ripe bananas can then be sold to rural middlemen or sold directly to the local market. Bananas sold to rural middlemen are usually freshly harvested and are still in raw condition. Sometimes, banana fruit is sold to rural middlemen when the fruit is still on the pseudostem (diborongkeun). In this system (diborongkeun), the treatment of fruit which is still on the pseudostem is undertaken by the middlemen.

\section{Utilization of banana production}

The banana fruit harvested from garden are usually sold and for home consumption. Most good grade quality of banana fruit productions are sold to local market, village middlemen or other middlemen who usually come to Palintang hamlet. Meanwhile, some banana fruit productions of low quality, including defective bananas and small banana hands of the end of bunch (butiti) that cannot be sold, are commonly used for home consumption. Generally, the upper hands of banana (tandan or sehang) on a bunch (turuy) are sold to middlemen. The fresh, not too-ripe bananas just harvested from garden were sold to fruit traders at a price between $\mathrm{Rp} 4.000$ and $\mathrm{Rp} 5.000$ per kilogram in 2018. While the ripe bananas which have been ripened were usually sold at a price between Rp. 5.000 and Rp 8.000 per kilogram. Some landraces have good selling prices in small shops (warung), including ambon bodas, ambon jepang, ambon lumut, and nangka (Rp5.000/kg); ampeang ( $\mathrm{Rp} 7000 / \mathrm{kg})$, raja cere raja bulu, and tanduk $(\mathrm{Rp} 10.000 / \mathrm{kg})$, astrali, galek $(\mathrm{Rp} 15.000 / \mathrm{kg})$. The price of banana fruit varies greatly among landraces and among grades of bananas. The most sold banana landrace in Palinang hamlet is cau ambon lumut because this landrace has some advantages, including having a lot of hands, large fruit size, good taste, and high economic value.

Traditionally, for home consumption, bananas have been differently used by rural people of Palintang. Ripe bananas are directly eaten as a dessert. Several banana landraces are usually consumed after cooking process (Table 4). For example, some banana landraces, namely cau astroli, golek, nangka, sewu, and tanduk are usually cooked, such as roasted (dibeuleum), burned in the ashes of a fireplace (dibubuy), steamed (diseupan), and fried (digoreng). In addition, bananas are also made into traditional cakes, including pisang goreng (fried flesh of ripe banana mixed with rice flour), nagasari (steamed flesh of ripe banana mixed with rice flour wrapped with banana leaves), and kolak pisang (boiled flesh of ripe banana mixed with brown sugar, and coconut milk) (Table 4).

Various traditional cakes made of bananas have commonly been consumed as ngaleueut or being eaten with a glass of tea or coffee in the morning and/or afternoon (cf. Igarashi 1985). Other parts of bananas, including leaves, pseudostems, and inflorences have also been used for several functions. For example, leaves of cau manggala have been used mostly for wrapping steamed rice (nasi timbel), while the pseudostems have been used as organic fertilizers. Ecologically, banana trees have been used as one of indicators as soil quality. According to the perception of informants (emic view), good bananas are usually indicators of good soils. It is confirmed by Western knowledge or literature (etic view) that bananas are plants of tropical humid, grown on wide range of soils provided there is good drainage with adequate fertility and moisture (Purseglove 1985).

Table 4. Various banana landraces and utilization by the rural community of Palintang, West Java, Indonesia

\begin{tabular}{|c|c|c|c|}
\hline \multirow{2}{*}{ Landraces } & \multicolumn{2}{|c|}{ Consumption of fruit } & \multirow{2}{*}{ Cooking process } \\
\hline & Fresh eaten & Cooked & \\
\hline Ambon bodas & $\checkmark$ & & \\
\hline Ambon Jepang & $\checkmark$ & & \\
\hline Ambo lumut & $\checkmark$ & $\checkmark$ & $\begin{array}{l}\text { Ripe banana is eaten as a dessert fruit, and ripe banana can be made into banana crakers } \\
\text { (kiripik pisang) }\end{array}$ \\
\hline Ampeang & $\checkmark$ & & \\
\hline Astrali & & & Fried, Steamed \\
\hline Bawel & $\checkmark$ & & \\
\hline Bogo & $\checkmark$ & & \\
\hline Gembor & $\checkmark$ & & \\
\hline Golek & & $\checkmark$ & Fried, Steamed \\
\hline Mangga*) & & & $\begin{array}{l}\text { *) Non ripe fruit is made into 'rujak ulek' (a non ripe banana fruit is mixed with cassava, } \\
\text { sweet potato, chili, sugar, and brown sugar is pounded. }\end{array}$ \\
\hline Muli & $\checkmark$ & & \\
\hline Nangka & & $\checkmark$ & $\begin{array}{l}\text { Fried, steamed, making of kolak (ripe banana, brown sugar, coconut milk, and water is } \\
\text { boiled); nagasari (a ripe banana and rice flour is steamed and wrapped with a banana } \\
\text { leaf); and other traditional cakes. }\end{array}$ \\
\hline Raja bulu & $\checkmark$ & $\checkmark$ & Fried, Steamed \\
\hline Raja cere & $\checkmark$ & $\checkmark$ & Fried and mixed with bread; steamed \\
\hline Ruhmid & $\checkmark$ & & \\
\hline Sewu & & $\checkmark$ & $\begin{array}{l}\text { Steamed, and usually drunk with 'bajigur' (Sundanese drink made of brown sugar and } \\
\text { young coconut) }\end{array}$ \\
\hline Susu & $\checkmark$ & & \\
\hline Tanduk & & $\checkmark$ & Fried, Steamed \\
\hline
\end{tabular}




\section{Changes of banana cultivation}

According to the environmental history, in the past, the Palintang hamlet was originally an enclave hamlet in the forest. During the Dutch colonial period, most people were involved as laborers in plantation in the forest area. During the Post-colonial period, most people were involved as laborers of intercropping (tumpang sari) program of the Perhutani forest. Due to economic development, intensive farming of commercial vegetable has been undertaken by Palintang people. Although providing high income for village community, this method of farming has caused some environmental disturbances, including forest destruction, soil erosion, landslide, and environmental pollution from pesticide uses. More recently, to avoid environmental destruction and to improve the rural household income, introduction of coffee and banana trees have been undertaken by the Perhutani involving Palintang people (Iskandar et al. 2017).

Before the introduction of coffee and banana intercropping in the forest of Perhutani, people of Palintang had traditionally planted various bananas in the homegardens and gardens. The planting of various bananas has been based on TEK embedded in their culture. The village internal inputs, including local sapling bananas and organic fertilizer have been intensively applied by Palintang farmers. The bananas production harvested from the homegardens and gardens have been used mainly for home consumption.

For the last decades, because of ecosystem and socioeconomic cultural changes, including conversion of forests to agricultural land, development of main road, increasing rural population, and intensive penetration of market economy system to rural area, the banana cultivation of Palintang people has changed. For example, the cultivation of bananas has applied not only organic fertilizers but also synthetic inorganic fertilizers. The pest management of banana trees has also applied synthetic pesticides instead of manual methods, including removing caterpillars that damaged the banana leaves as practiced in the past. New varieties of banana saplings have also been introduced. In addition, most of the production of bananas have been sold instead of being consumed for fulfilling household need. Therefore, the cultivation of bananas in Palintang has changed due to changes of ecosystem and socio-economic and cultural aspects of rural people of Palintang hamlet.

In conclusion, the Palintang community has cultivated 18 varieties of bananas for long time based on their TEK embedded in their culture. However, the traditional method of banana cultivation which was environmentally friendly has been replaced by intensive farming due to the ecosystem, socio-economic and cultural changes in the community. $\square$

\section{ACKNOWLEDGEMENTS}

This research was done with the support of many people. Therefore, we would like to thank informants and respondents of Palintang People, Cipanjalu Village, Cilengkrang Sub-district, Bandung District, West Java,
Indonesia who kindly helped us with information on many aspects of local knowledge on banana in their hamlet. Dissemination and the publication of this research were financially supported by the Academic Leadership Program (ALG) with the topic, 'Ethnobiology for Public Welfare'. Accordingly, we would like to thank to Prof. Trihanggono Achmad, Rector of Padjadjaran University, who supported the ALG program.

\section{REFERENCES}

Bellow TS, Fisher FW. 1999. Biological Control: Principles and Applications of Biological Control. Academic Press, San Diego, USA.

Berkes F. 2008. Sacred Ecology. Routledge, New York.

Berlin B, Breedlove DE, Raven PH. 1973. General principles of classification and nomenclature in folk biology. Amer Anthropol 75: 214-242.

Boyd R, Richerson PJ. 1985. Culture and the evolutionary process. University of Chicago Press, Chicago.

Burkill IH. 1935. A dictionary of the economic product of the Malay Peninsula. Crown Agents for the Colonies, London.

Creswel JW. 2009. Research design: qualitative, quantitative, and mixed methods approach. Sage Publications, London.

Dove MR, Sajise PS, Doolittle AA. 2005. The problem of conserving nature in cultural landscape. In Dove MR, Sajise PS, Doolittle AA. (eds), Conserving in Culture: Case Studies from Southeast Asia. Yale University Southeast Asia Studies. New Haven, Connecticut.

Ellen RF, Harris H. 2000. Introduction. In Ellen, Parkes P, Bicker A. (eds). Indigenous environmental knowledge and its transformation: critical anthropological perspective. Hardwood Academic Publishers, Amsterdam.

Ekawati I, Purwanto Z. 2012. Potential agricultural waste as an alternative source of potassium calcium and magnesium nutrients for supporting plant production sustainability. National Seminar of Food and Energy Sovereignty in Bankalan, June 2012. University of Trunojoyo, Bangkalan [Indonesian].

Fitriyah A, Ariyanti EE, Damanhuri, Kuswanto. 2017. Grouping of 30 species of Banana (Musa spp.) based on genome and kinship relationship. J Plant Product 4 (5): 568-575 [Indonesian].

Hapsari L, Kennedy J, Lestari DA, Masrum A, Lestarini W. 2017. Ethnobotanical survey of bananas (Musaceae) in six districts of East Java, Indonesia. Biodiversitas 18 (1):160-174.

Hehakaya MA. 2010. Study on people knowledge on variations, utilization, processing, and cultivation of Bananas (Musa spp.) in Sukajaya village, South Sumedang Sub-district, Sumedang District. Research report of Biology Department, Faculty of Mathematics and Natural Sciences, Padjadjaran University, Sumedang [Indonesian]. $\square$

Hewlett BS, Cavalli-Sforza LL. 1986. Cultural transmission among aka pygmy. Amer Anthropol 88: 922-934.

Igarashi T. 1985. Some notes on the subsistence in a Sundanese village. In Suzuki S, Soemarwoto O, Igarashi T. (eds). Human ecological survey in rural West Java in 1978 to 1982. Nissan Science Foundation, Tokyo.

Iskandar J, Iskandar BS. 2005. Alternative medicine of Baduy. Humaniora, Bandung.

Iskandar J, Ellen RF. 2007. Innovation, 'hybrid' knowledge and the conservation of relict rainforest in upland Banten. In: Ellen RF. (ed), Modern crises and traditional strategies: local ecological knowledge in island Southeast Asia. Berghahn Books, New York. $\square$

Iskandar J. 2016. Ethnobiology and cultural diversity. Umbara, Indonesian J Anthropol 1 (1): 27-42. [Indonesian].

Iskandar J. 2018. Ethnobiology, Ethnoecology and Sustainable Development. Plantaxia, Yogyakarta.

Iskandar J, Ellen RF. 1999. In situ conservation of rice landraces among the Baduy of West Java. J Ethnobiol 19 (1): 97-125.

Iskandar J, Iskandar BS. 2011. Agroecosystem of Sundanese people. Kiblat Buku Utama, Bandung.

Iskandar J, Iskandar BS. 2015. Study on botany regarding diversity of food plants in the swidden farming system in supporting of food 
safety of the Baduy community. Pros Sem Nas Masy Biodiv Indon 1 (6): 1265-1272. [Indonesian]

Iskandar J, Iskandar BS. 2016a. Ethnoecology and agroecosystem management in Karangwangi village, Cidaun District, South Cianjur. J Biodjati. 1 (1): 1-12.

Iskandar J, Iskandar BS. 2016b. Plant architecture: homegraden structure and urban green open space. Teknosain, Yogyakarta [Indonesian]

Iskandar J, Iskandar BS. 2016c. Ethnoastronomy-the Baduy agricultural calendar and prediction of environmental perturbation. Biodiversitas 17 (2): 694-703.

Iskandar J, Iskandar BS. Partasasmita R. 2016. Responses to environmental and social-economic changes in Karangwangi traditional agroforestry, South Cianjur, West Java. Biodiversitas 17 (1): 332-341

Iskandar BS, Iskandar J, Wibawa HA, Partasasmita R. 2017. Farmers and tumpang sari: case study in Palintang hamlet, Cipanjalu village, Bandung, Indonesia. Biodiversitas 18 (3): 1135-1149.

Iskandar J, Iskandar BS. 2018. Ethnobiology, rice biodiversity and rice cultivation modernization: Case study in Baduy and Naga community. J Biodjati 3 (1): 47-62.

Iskandar BS, Iskandar J, Irawan B, Partatasmita R. 2018a. Traditional market and diversity of edible plant trading: Case study in Ujungberung, Bandung, West Java, Indonesia. Biodiversitas 19 (2): $437-452$.

Iskandar J, Iskandar BS. Partasasmita R. 2018b. Review: the impact of social and economic change on domesticated plant diversity with special reference to wet rice field and homegarden farming of West Java, Indonesia. Biodiversitas 19 (2): 502-514.

Iskandar J, Iskandar BS, Partasasmita R. 2018c. Site selection and soil fertility management by the Outer Baduy People (Banten, Indonesia) in maintaining swidden cultivation productivity. Biodiversitas 19: 1334-1346.

Kalshoven LGE. 1981.The pest of crops in Indonesia. Revised and translated by Van der Laan PA, Ichtiar Baru-Van Hoeve T., Jakarta.

Karyono. 1981. Structure of Homegardens in Village of Citarum River Basin. [Dissertation]. Padjadjaran University, Bandung.

Kusumaatmadja S 2001. Fair utilization and sustainable in the era of the regional autonomy: biodiversity with new civilization. Indonesian Diversity Forum, Jakarta. [Indonesian]

Lynch SJF, Hoelnsteiner RM, Cover CL. 1974. Data Gathering by Social Survey. Philippine Social Science Council, Quezon City.

Lizarralde M. 2004. Indigenous knowledge and conservation of rainforest: ethnobotany of the Bari of Venezuela. In: Carlson TJS, Maffi L. (eds), Ethnobotany and Conservation of Biocultural Diversity. The New York Botanical Garden Press, New York.
Lovelace GW. 1984. Cultural beliefs and management of agroecosystems. In Rambo AT, Sajise PE. (eds), An Introduction to Human Ecology Research on Agricultural Systems in Southeast Asia. East-West Center, Hawaii.

Martin G J. 1995. Ethnobotany: A Method Manual. Chapman and Hall, London.

Meltin L. 2009. Cultivation of Spring Onion (Allium fistulosum L.) in Horticultural Seed Garden (KBH). [Hon. Thesis]. Faculty of Agriculture, University of Sebelas Maret, Surakarta [Indonesian].

Newing H, Eagle CM, Puri RK, Watson CW. 2011. Conducting research in Conservation: social science methods and practice. Routledge, London.

Puri RJ. 1997. Hunting Knowledge of the Penan Benalui of East Kalimantan, Indonesia. [Dissertation]. Department of Anthropology, University of Hawaii, Hawaii.

Purnomo EA, Sutrisno E, Sumiyati S. 2017. The effect of C/N variations on compost production and potassium $(\mathrm{K})$ content, phosphate $(\mathrm{P})$ from banana stems with a combination of cow manure in a vermicomposting. J Environ Eng 6 (2): 1-15 [Indonesian].

Pratiwi IT, Wibowo L, Indriyanti, Purnomo. 2014. Inventory of banana leaf rollers parasitoid (Erienota thrax L.) in South Lampung regency. J Trop Agrotech 2 (3): 459-464 [Indonesian].

Purseglove JW. 1985. Tropical Crops: Monocotyledons. volume 1 and 2 combined. Longman Group Limited, Essex, England.

Rahmawati M, Erita H. 2013. Grouping based on the characteristics of vegetative morphology in germplasm banana from Aceh Besar Regency. J Agrista 17 (3): 111-118 [Indonesian].

Ridhyanty SP, Julianti E, Lubis LM. 2015. Effect of ethepon giving as stimulating material maturation of the quality of barangan banana fruit (Musa paradisiaca L.). J Food Agric Eng 1 (3): 1-13.

Sriharti, Salim T. 2008. Utilization of banana waste for making compost using a rotary composter drum. Proceeding of National Seminar Teknoin, 22 November 2008, Yogyakarta [Indonesian].

Sundarnadi H. 1996. Monocotyl plant. Penebar Swadaya, Jakarta [Indonesian].

Warsito H. 1992. Introduction to Research Methodology: Student Guide Book. Gramedia Utama, Jakarta [Indonesian].

Widjaja EA, Rahayuningsih Y, Rahajoe JS, Ubaidillah R, Maryanto I, Waluyo EB, Semiadi G. 2014. Recent Biodiversity of Indonesia. Lipi Press, Jakarta.

Yenrizal. 2015. Rural Farmer Community Environmental Communication: Study Communication Ethnoecology of the Semende Community in Swarna Dwipe village, Muara Enim District, South Sumatra. [Dissertation]. Faculty of Communication, Padjadjaran University, Sumedang. 